\title{
Financial innovations, the evaluation of their application in Southeastern Europe: the case of the Republic of Moldova
}

\author{
Ph.D. Associate prof. Maia Pisaniuc \\ Academy of Economic Studies of Moldova (ASEM) \\ International Business Department
}

\begin{abstract}
Financial innovations are an invaluable element in the framework of knowledge economy. Fintech has already become a must-have for most countries in the world. These innovations represent a reformative element of the current banking activity, as well as a new innovative business model. The purpose of this paper is to analyse the development level of these innovations on the market in Romania and the Republic of Moldova. This study attempts to apreciation to which extent the economies of these countries are ready to face the challenges, which the tendencies and opportunities of the banks are in order to embrace the latest technologies and to evaluate the impact of the latest financial technologies on the banking sector in the Republic of Moldova.
\end{abstract}

Research methods used: comparative analysis, induction, deduction, forecast based on data analysis.

Key words: fintech, banking online, block chain, crowd funding, p2p credit.

Classification JEL: G10

Classification REL: 11A

\section{Introduction}


An increasing number of new revolutionary technologies have lately changed our society and businesses. Revolutionary innovations have changed the well-established practice and have led to the emergence of new industries, and concurrently to the reorientation of some of them, to another development stage. Innovation is regarded as the result of a process that starts with an idea development and continues with its implementation. The Oslo Handbook (2005) defines innovation as an activity that results in a new or significantly improved good (product or service), a new process, a new method of marketing and business organisation.

Innovation on a technological basis applied globally, has led to the notion of "FinTech", which can be widely defined as a financial innovation on a technological basis, and as a result contributes to the emergence of new business models, applications, processes or products. The most noticeable effects are on financial markets, in financial institutions by providing financial services (Carney (2017)).

The digital revolution has had a major influence on all areas of human activity, but probably the most essential impact is exerted on human behavior, which has undergone major and radical changes due to the penetration of mobile telephony and the Internet in the daily lives of all people, regardless of the level of education, qualification, financial status or field of activity, etc. The main challenge that arises from all these is the perpetual change of the clients' demand, who will request banking services of a similar quality to those in the field of information technology.

\section{Regional tendencies of Finteh application}

The Digital Europe Program is meant to support the development of financial innovations from 2021 to 2027, which aims to strengthen Europe's strategic digital capabilities focusing, in particular, on supercomputing, artificial intelligence, cyber security and advanced digital skills, as well as ensuring the use of large-scale digital capacity throughout the entire economy and society. Likewise, at EU level they have provided a new investment facility for the development of digital start-ups in Central, Eastern and South-Eastern Europe: The European Commission, together with the European Investment Bank, the European Investment Fund, the European Bank for Reconstruction and Development, the World Bank and the International Financial Corporation will launch the Digital Innovation and Development of Digital Companies (DISI) Initiative.

This will be the first regional investment facility that will specifically target digital innovations and the development of digital start-ups in Central, Eastern and Southeast Europe. As a result, FinTech is being promoted both by governments and international institutions, and is being quickly overtaken by all users of financial and banking services.

The major macroeconomic role of financial technologies stems from their enormous contribution to enhancing financial access, currently being qualified as one of the major impediments to sustainable and inclusive development.

FinTech generates new risk management solutions. For example, at the moment, the blockchain represents the perfect technology for maintaining anonymity, and on the other hand much alike is 
the technology that can transform the transactions with bitcoins from anonymous to identifiable ones, authenticating the identity in a much more robust way than all those that already exist. Thus, the blockchain contributes positively to the management of compliance risk by conforming to the KYC (Know Your Customer) and AML (Against Money Laundering) laws. This fact will contribute to the acceptability of crypto currencies from the states' perspective, along with the capitalization of the other advantages.

An eloquent example of fintech is Revolut that allows users to open a current account in the app in a few minutes, make free domestic and international transfers, own and exchange 25 currencies in the app using the real exchange rate (interbank) and spend money worldwide, in 130 currencies, without any hidden fees and commissions, using a contactless VISA or MasterCard.

Another innovation is the German fintech N26 which is considered to be the first mobile bank in Europe that raised 300 million euros in the last financing round, helping the company to be evaluated at 2.7 billion euros, thus becoming the largest European unicorn.

Being based in Berlin, the company offers customer mobile banking services on 24 markets in Europe and has over 2.3 million registered app users. It also manages over 1 billion euros in customers' current accounts, which generates over 1.5 billion transactions per month through currency transfers or exchanges.

In order to back up innovation, the European Securities and Markets Authority (ESMA) set out its priorities for 2019 and established the budget and number of employees required in its main areas of interest. In this regard, the EU financial market regulator announced that it will allocate 1.1 million euros to monitor activities in the fintech and crypto currency area. The Agency explained that, in order to ensure the financial well-being of the block, it will pay greater attention to financial innovations, including the cryptocurrency market, closely monitoring the problems and risks associated with these activities.

In this regard, the National Bank of Romania also announced the launch of the FinTech Innovation Hub project, a platform dedicated to dialogue with companies that develop innovative solutions of general public interest in the field of payment and financial services - fintech. As early as spring 2017, the European Banking Authority conducted a mapping exercise for the better understanding of the financial services offered and the innovations implemented by Fintech companies in the EU, and their regulatory framework. The exercise was carried out on a sample of 282 Fintech companies, reported by competent authorities, some of them being regulated according to the EU legislation or the national financial services, others being identified as not regulated according to the legislation on financial services. Following the mapping exercise, there were identified several groups of financial services which are included in the field of technological financial innovations. 
Figure 1. Financial products and services

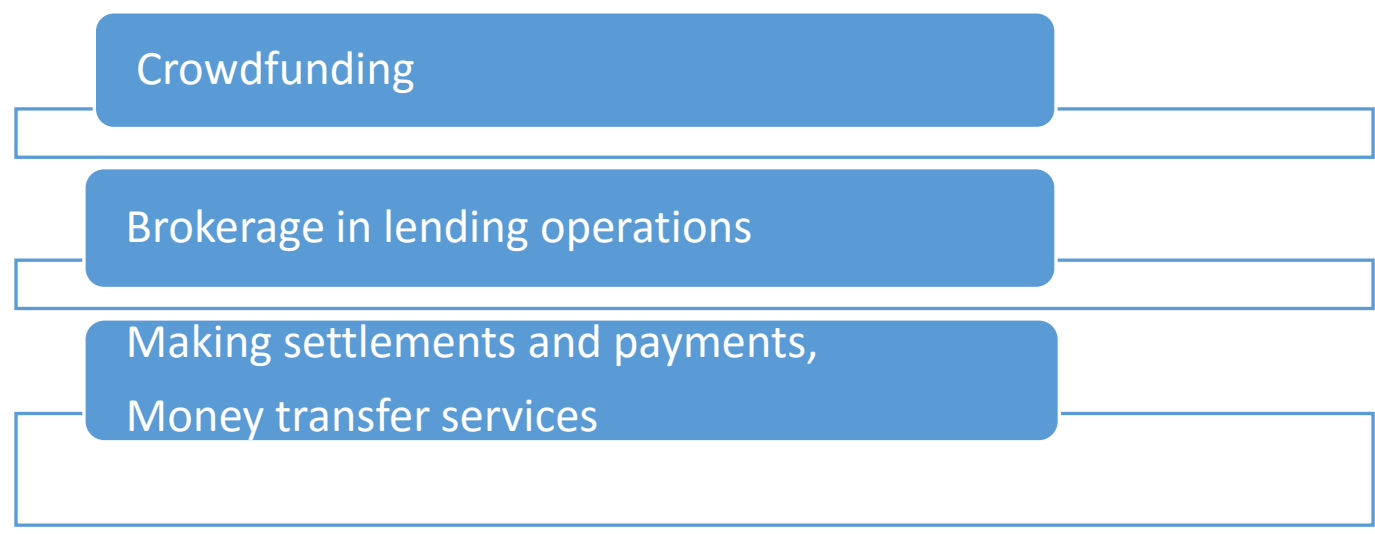

Creation of payment instruments for credit money

\section{Asset management and investments}

\section{Crowdinvesting}

Modern financial products that banks or specialised companies offer or will offer in the near future require Internet access and the usage of appropriate technical equipment. Credit institutions are ready to finance the acquisition of new technologies and their development. Over $50 \%$ of banks intend to cooperate with other specialised institutions in order to develop similar projects, while others want to manage this individually. Banks that choose to develop in-house projects need welltrained personnel in the field of financial technological innovation.

According to the Global Banking Outlook 2017 report, the challenge of financial institutions is to build an infrastructure, culture and network of investment-oriented partners in innovation, in order to evolve into an extremely competitive market.

An analysis of the preliminary data for the first half of 2018 shows that global investments in fintech reached 57.9 billion dollars in 875 contracts, which is a significant increase compared to 38.1 billion dollars invested throughout the entire year in 2017. 
A recent global survey conducted by KPMG shows that financial institutions perceive fintech as the main driver of change in the sectors they operate in. According to the survey, banks, insurers and investment management companies believe that technologies like artificial intelligence, block chain and Internet of things will essentially redefine financial services. However, only a small number of financial institutions (22\%) have developed a fintech strategy aligned with the challenges imposed by the rapid innovation in this field.

At the same time, the majority of respondents considered that partnerships with start-ups are necessary in the fintech domain, $61 \%$ of them indicated they have already made such partnerships and $81 \%$ expressed their intention to make partnerships with fintech companies in the near future. However, half of the respondents also expressed their intention to find fintech solutions internally, which shows that innovation in the field is not left for start-ups.

\section{The analysis of implementation possibilities of Finteh in Southeastern Europe}

Under the current circumstances, banks must excel and compete not only with banking institutions, but also with alternative providers of banking services, financial consulting companies, insurance companies, etc.

In Romania, credit institutions have made major efforts regarding the development of new technologies, products and services, in order to improve customer experience in online banking. The emergence of new technologies can lead to changes in the banking strategy by increasing the scope of eligible customers. Fintech-type projects initiated by credit institutions in Romania are as follows: Authentication, DLT, Block chain, Big Data, peer-to-peer transactions, Artificial Intelligence, Robotic Process Automation, Chatbot, Video Advisory, Natural Language Understanding. They envisage payment systems, the sale of banking products and services, advertising and customer orientation. According to banks, the benefits that Fintech projects bring are both cost efficiency, by transferring the interaction with customers to the online environment, and the increase in the number of customers, including foreign customers. The banks also take into account the risks associated with the projects, which are evaluated on the basis of internal methodologies or at group level. In general, credit institutions claim that they have an average appetite level for the risk associated with the Fintech phenomenon. Credit institutions in countries such as the Republic of Moldova, Bulgaria and Romania should consider digitisation as an opportunity and under no circumstances a threat. It is necessary for Fintech companies to realise that in order to function efficiently and to make a profit, they cannot destabilise the entire value chain of commercial banks.

Cooperation between banks and Fintech companies is essential for the success of Fintech-type projects, and its lack can make the difference between survival and success. Differences of economic and social nature among the population of Romania and the Republic of Moldova can create important barriers in the development of Fintech in Romania. Many people from the rural areas do not use the internet or telephony services, which results in reduced access to modern financial products. 
Other factors that may present barriers to the development of the Fintech segment are the low degree of financial inclusion and the population's low level of trust in the services rendered by banks. Mistrust in the banking sector generates a low level of demand for internet services for the purpose of carrying out financial activities. By comparing credit institutions with Fintech companies, we can see advantages for each.

Thus, the banks' strength depends on: the existence of databases with clients, the ownership of capital needed to maintain their clients, but as for the advantages of Fintech companies, there have been witnessed lower rates compared to banks, transparency (everything is made visible, which results in lower costs), a faster execution of operations on the online environment. Customers feel that banks do not offer them significantly different advantages compared to the new types of banks and technology-based companies, even when offering financial advice. The development of this domain is also driven by the increasing level of IT services.

Table N 1. Typology and structure of IT services outsourcing market over 2019-2024

\begin{tabular}{|l|l|l|l|l|l|l|}
\hline $\begin{array}{l}\text { Outsourcing } \\
\text { market }\end{array}$ & 2019 & 2020 & 2021 & 2022 & 2023 & 2024 \\
\hline IT services & 99,4 & 110,49 & 117,61 & 124,70 & 130,79 & 136,53 \\
\hline BPO & 17,66 & 20,46 & 23,15 & 26,30 & 28,24 & 30,42 \\
\hline $\begin{array}{l}\text { R\&D/ } \\
\text { Engineering }\end{array}$ & 17,31 & 20,28 & 23,03 & 25,45 & 28,12 & 30,94 \\
\hline $\begin{array}{l}\text { Other } \\
\text { (management, } \\
\begin{array}{l}\text { Quality } \\
\text { Assurance) }\end{array}\end{array}$ & 9,76 & 11,38 & 12,77 & 15,06 & 16,09 & 17,22 \\
\hline
\end{tabular}

Source: Elaborated by author based on statistical data

Fintech companies have already moved to basic banking services, including lending. Currently, fintech credit represents only a very small percentage of global credit, but it is growing rapidly and could become more prevalent in certain market segments. In the United States, for example, $36 \%$ of unsecured personal loans were issued by fintech companies in 2017.

Within this study, the term "FinTech credit" covers all the credit activity facilitated by electronic platforms, through which debtors are directly connected with creditors. These entities are commonly referred to as "loan-based crowd funders", "peer-to-peer (P2P) lenders" or "market lenders". These electronic platforms can facilitate a number of credit obligations, including secured and unsecured loans and non-repayable financing, such as financing invoices. In addition, some electronic platforms go beyond a P2P-compliant business model by using their own balance sheet for lending activities.

First of all, there will be analysed the various factors that determine FinTech innovations; Supply factors

- FinTech lenders might use digital innovations more intensively. For example, FinTech Lenders automatise far more processes than traditional credit providers, and thus provide customers with a relatively convenient and fast service. Moreover, FinTech lenders can use new data sources. 
- A typical feature of platform-based business models is their ability to produce low investment costs and digital contact with their potential customers.

- Traditional creditors have a relatively high fixed cost base because of branch networks and the need to maintain their current IT systems. They also face higher capital and liquidity requirements for loans than through FinTech credit platforms outside the prudential regulatory segment. These factors represent advantages for online lending platforms. As their activities are fundamentally structured similarly to those of banks, FinTech credit platforms could benefit from the regulatory arbitrage.

- Traditional lenders have left room for new entrants into the lending market. In addition, banks often "under-value" certain market segments, such as micro-business loans (De Roure and al. (2016)). In certain cases, fiscal policies and regulations may encourage lending through alternative platforms to these segments. In other cases, the yield earned from rents can encourage the development of platforms.

- The real-time trading capacity of the devices connected to the internet has triggered the increase of customers' expectations in terms of convenience, speed, cost and easy use of the financial services. Consumer comfort with online financial transactions has also increased as online business innovations have expanded.

- There are demographic factors related to the change in customer expectations, that have led to demand for these loans, such as the growing acceptance of new technologies, which has led to increased demand for financial products, that is influenced by cohorts known as "new generation" and "millennials". These are younger cohorts that are more likely to adopt FinTech (EY (2016)).

- Consumers may now be more willing to use the services of credit market operators due to their low confidence in the creditors left after the financial crisis. A more general perception of some consumers might be that FinTech credit, and especially P2P loans, are more socially responsible and have a higher social value than conventional bank credits (Milne and Parboteeah (2016)).

- In some large economies, the desire for higher yields versus lower yields has provided FinTech platforms with a larger base of investors, including institutional investors. Investors may consider FinTech loans an alternative class of assets that may lead to the diversification of their portfolios.

- Technological innovations often display the externalities of the network that determine the demand. As for FinTech loans, it is possible that the number of investors dictate the demand for lending on platforms.

However, some factors may hinder the pace and extent of FinTech credit growth.

- There might appear competitive responses from FinTech creditors.

Banks have been developing their digital banking business for several years and the emergence of market lending platforms has accelerated this process.

- The growth of the FinTech lending industry could be hindered by business models that are not trustworthy, in a less favorable lending or financing environment. The causes might be certain business models that are, generally, opaque and /or prove to be risky. Moreover, most FinTech creditors have not experienced a complete credit cycle. Therefore, which way lending on platforms will witness a decline is uncertain. 
Another factor are the regulatory requirements regarding lending activities in various jurisdictions, such as the need to be authorized and regulated as an online lending platform or the need to be authorized and regulated as a bank or credit intermediary to offer consumer loans, or to keep loans on the balance sheet. For example, in Japan, legislative ceilings for interest rates make obtaining loans from FinTech platforms more difficult for risky consumers.

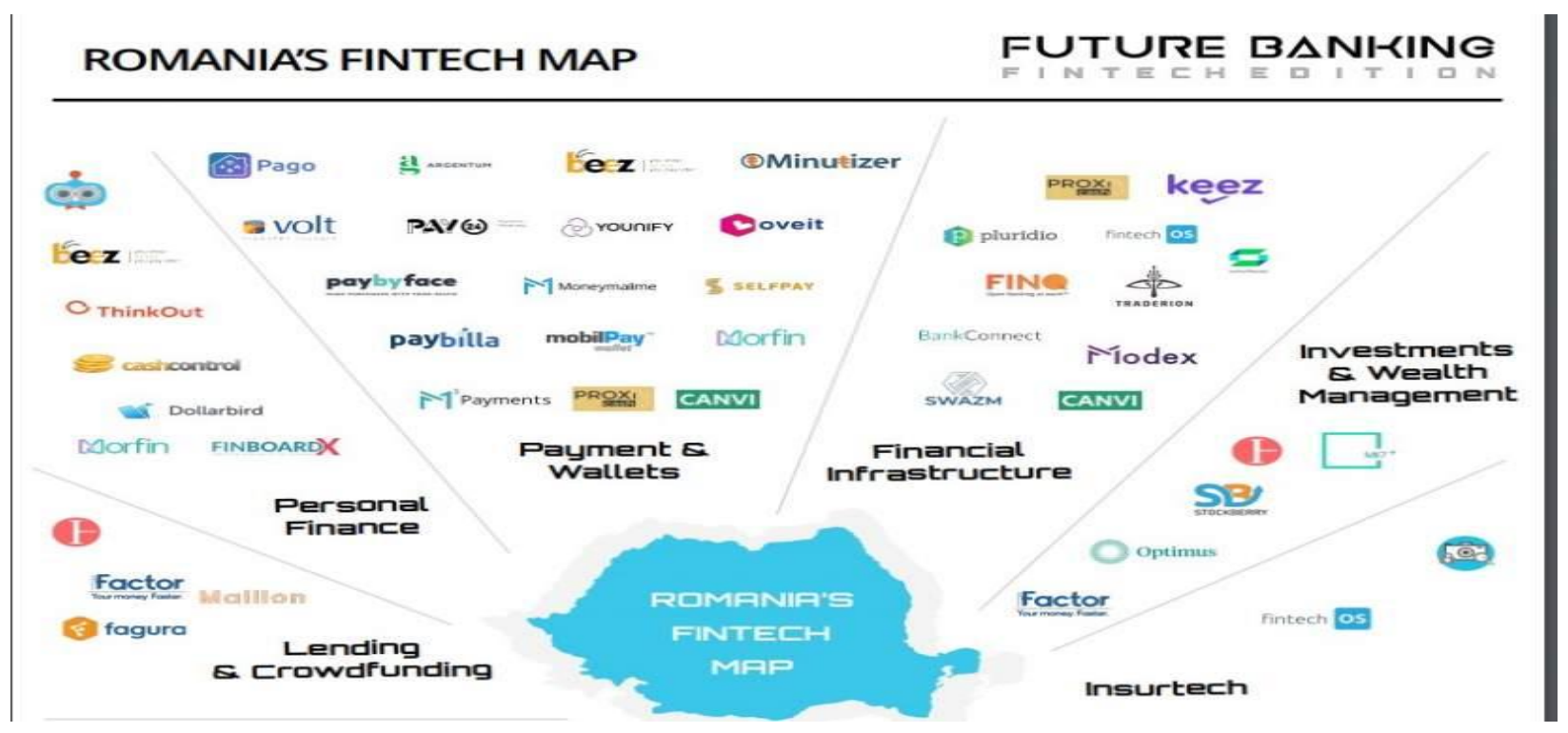

Fagura, the first credit marketplace in Moldova, was included in the first map of the Romanian FinTechs.

The FinTech industry is witnessing increased attention worldwide, attracting investments of over $\$ 15$ billion in the first half of this year.

Eloquent examples of Fintech in the Republic of Moldova are Saltedge, Fagura or Qsystems, which have international products.

The IT sector is strategic for the Republic of Moldova and the IT industry is very competitive and generates high added value. In 2018, the IT service market reached \$ 154.4 million and is expected to increase to $\$ 262.26$ million by 2024 .

It is obvious that the presence of Fintech is very insignificant, and is not creating competition for commercial banks at the moment, but this is the first attempt. Meanwhile, commercial banks currently widely use modern financial technologies.

The title for innovation has been attributed to the Mobile Cash service, unique on the market of the Republic of Moldova and other countries in the region, which allows customers to quickly and easily withdraw or replenish the card account at the Moldindconbank ATMs using only the mobile phone.

In terms of innovations, in the Payments category, Moldindconbank is placed alongside 9 other Fintech banks and companies worldwide: Alfa Bank (Russia), China Guangfa Bank, DBS 
(Singapore), FAB (First Abu Dhabi Bank, United Arab Emirates), Mashreq (United Arab Emirates), Millenium bim Mozambique (Mozambique), NBK (Kuwait), Nuggets and Telenor Microfinance Bank (Pakistan).

$\mathrm{BC}$,Moldova Agroindbank” SA (MAIB) is a universal systemic bank, geared towards providing financial, innovative and high-tech services to all customer segments. MAIB uses the latest trends in providing financial services, such as: American Express cards - MAIB is the exclusive representative of American Express in the Republic of Moldova and holds an exclusive license on the market of the Republic of Moldova to issue and accept cards with the American Express brand; the contactless payment technology is offered through the bank cards of three international payment systems: MasterCard, Visa and American Express. The innovation supposes performing "contactless" transactions at POS-Terminals by simply approaching the terminal card, without handing it to the cashier; premium cards - MAIB offers the widest range of premium cards - MasterCard Gold, MasterCard Platinum, MasterCard World Elite, Visa Gold, Visa Platinum, American Express Gold Credit, American Express Gold Debit;

Bancassurance project - thanks to this project, customers can access any type of insurance directly inside the bank; the MAIBank mobile application - you have an entire bank in your phone; 3D Secure service having a dynamic password and ISO 27001: 2013 - the highest security standards applied by the bank on card and online operations, etc.

Another bank that has acquired the title of an innovative bank is Victoriabank SA. This title was offered by the international payment system for the introduction of HCE (Host Card Emulation) technology on the domestic market, which allows a phone to perform card emulation on a device with NFC (Near Field Communication) communication, thus simplifying the payment process for cardholders. The technology was first introduced on the market in the Republic of Moldova in 2017 by Victoriabank, and so far it remains the single bank in the country that offers its customers the possibility to make payments from their smartphone.

Another problem is the unwillingness of the bank staff to quickly adjust to the market requirements, because this will automatically lead to the redundancy of staff working mainly in the retail segment. We reckon that the innovation of banks might be driven only by the appearance of more Fintech companies on the market, which are small in size, very flexible, offer lower costs and increased service speed.

\section{Conclusions}

The Fintech industry will escalate as different regulatory priorities, technological capabilities, as well as customer needs, raise challenges to the tendency towards financial globalization and pave the way for regional models of financial services, tailored to local conditions. In this regard, international companies may also need clear strategies to benefit from regional competitive advantages and to adapt to local ecosystems.

The development of this industry will contribute to the redistribution of profit: The location of the profit centres inside, as well as between the value chains of supply changes along with the new technologies, as it will lead to data monetisation, and to the use of artificial labor force, but also to 
the reduction in the expenses for financial service costs, by reducing the staff, and expanding the branch network.

Analysing the level of development of Fintech on a regional level, we can conclude that it is still in its incipent phase. The potential of implementation of this domain is still growing which is due to the increasing usage of informational technologies by clients, higher profitability compared to traditional banks, and not least the speed and efficiency in serving clients.

\section{Referneces :}

\section{Angela BELOBROV IMPACTUL DEZVOLTĂRII INDUSTRIEI FINTECH ASUPRA} ACTIVITĂŢII BANCARE TRADIŢIONALE, 2016, www.irec.md 2.FinTech credit, Market structure, business models and financial stability implications Report prepared by a Working Group established by the Committee on the Global Financial System (CGFS) and the Financial Stability Board (FSB), 2017Bank for International Settlements and Financial Stability Board 2017.

.ISBN 978-92-9259-051-2 (online)

3. EY: The EY FinTech Adoption Index: exploring a new financial services landscape, January. 2016

3. Ozili, P., K., Impact of digital finance on financial inclusion and stability, 2017

4. Consultative Group to Assist the Poor- What is Digital Financial Inclusion and Why Does it Matter? 2015

5.De Roure, C, L Pelizzon and P Tasca: "How does P2P lending fit into the consumer credit market?", Deutsche Bundesbank Discussion Papers, no 30/2016.

6.Milne, A and P Parboteeah : The business models and economics of peer-to-peer lending, European Credit Research Institute, May.2016

7.Carney, M : "The promise of FinTech - something new under the sun?", speech at the Deutsche Bundesbank G20 Conference on Digitising finance, financial inclusion and financial literacy, Wiesbaden, 25 January 2017

8. Fintech and Financial Stability- Exploring how technological innovations could impact the safety \& security of global markets, 2017

9. World bank- Digital Finance: Empowering the poor via new technologies, 2014

10.Bank for International Settlements- Implications of fintech developments for bank and bank suvervisors, 2018;

11. Financial Stability Board- http://www.fsb.org/what-we-do/policy-development/additionalpolicy-areas/monitoringoffintech/

12. https://www2.deloitte.com/ro/ro/pages/about-deloitte/articles/world-economic-forum-sideloitte-dincolo-de-fintech-o-analiza-pragmatica-a-potentialului-disruptiv-al-tehnologiei-pentrusectorul-serviciilor-financiare.html

13.https://noi.md/md/economie/care-este-prognoza-dezvoltarii-pietei-serviciilor-it-in-moldovapina-in-2024

14.www.pwc.com/fstech2020 
15.https://www.juridice.ro/553951/kpmg-peisajul-fintech-la-nivel-global-este-dominat-desolutii-inovatoare-ce-vor-transforma-radical-serviciile-financiare.html 